\title{
Pengaruh Discharge Planning Model LIMA terhadap Kesiapan Pulang pada Pasien dengan Diabetes Melitus
}

\author{
Eka Yulia Fitri ${ }^{1}$,Dhona Andini ${ }^{2}$, Jum Natosba ${ }^{3}$
}

1,2,3 Bagian Keperawatan Fakultas Kedokteran Universitas Sriwijaya

\begin{tabular}{|c|c|}
\hline Article Info & Abstract \\
\hline $\begin{array}{l}\text { Article History: } \\
\text { Diterima } 27 \text { Mei } 2020 \\
\text { Key words: } \\
\text { Perencanaan pulang; } \\
\text { perawatan paliatif; penyakit } \\
\text { kronis; diabetes melitus }\end{array}$ & $\begin{array}{l}\text { Discharge planning atau perencanaan pulang bertujuan untuk } \\
\text { mempertahankan kontinuitas perawatan lanjutan di rumah setelah pasien } \\
\text { dipulangkan dari rumah sakit. Discharge planning yang efektif mampu } \\
\text { menjamin pasien dan keluarga melakukan tindakan perawatan paliatif } \\
\text { lanjutan yang aman dan realistis setelah meninggalkan rumah sakit. Tujuan } \\
\text { penelitian ini adalah untuk mengetahui apakah ada pengaruh penggunaan } \\
\text { discharge planningmodel LIMA terhadap kesiapan pasien dengan penyakit } \\
\text { diabetes melitus dan keluarga dalam menghadapi pemulangan. Metode } \\
\text { penelitian yang digunakan dalam penelitian ini adalah studi korelasi dengan } \\
\text { pendekatan quasi eksperimental yang dilakukan di dua ruang rawat inap } \\
\text { pada RS X Palembang. Sebanyak } 31 \text { pasien diabetes melitus dinilai skor } \\
\text { kesiapan pulang sebelum dan setelah intervensi discharge planning model } \\
\text { LIMA dengan menggunakan kuesioner RHDS. Hasil penelitian menunjukkan } \\
\text { bahwa ada perbedaan yang signifikan dalam skor rata-rata kesiapan pulang } \\
\text { pre-test dan post-test, yang berarti bahwa ada pengaruh discharge } \\
\text { planningmodel LIMA terhadap kesiapan pulang di antara pasien dengan } \\
\text { diabetes melitus. }\end{array}$ \\
\hline
\end{tabular}

\section{PENDAHULUAN}

Discharge planning merupakan salah satu indikator penentu keberhasilan pelayanan kesehatan di rumah sakit (Nursalam, 2014). Rorden \& Taft (1990) mendefinisikan discharge planning sebagai suatu proses yang terdiri dari beberapa langkah tindakan antisipasi terhadap perubahan kebutuhan perawatan bagi pasien, dan untuk memastikan kontinuitas pelayanan kesehatan bagi pasien (Dougherty, Lister \& West-Oram, 2015). Manfaat pemberian discharge planning adalah pasien dan atau keluarga mampu melakukan perawatan secara mandiri setelah pulang dari rumah sakit.

Hasil penelitian Ernita, Rahmalia, \& Novayelinda (2015) menunjukkan bahwa pemberian discharge planning pada pasien TB memberikan kesiapan yang baik bagi pasien dan keluarga dalam menghadapi pemulangan $(71,43 \%)$. Dan penelitian oleh Serawati, Suryani, \& Astuti (2015) menunjukkan bahwa 94,6\% pasien nifas menyatakan siap pulang ke rumah setelah dilakukan discharge planning. Kesiapan

Corresponding author:

Eka Yulia Fitri

ekayulia_01@unsri.ac.id

Jurnal Kepemimpinan dan Manajemen Keperawatan, Vol 3 No 1, Mei 2020

DOI: http://dx.doi.org/10.26594/jkmk.v3.i1.443

e-ISSN 2621-5047 
tersebut antara lain kesiapan dalam mengkonsumsi obat sesuai dosis dan aturan pemakaian obat yang dianjurkan, serta mengetahui tanda bahaya post partum.

Pasien dengan diabetes melitus sangat memerlukan discharge planning sebelum kembali ke rumah. Pada pasien dengan diabetes melitus terdapat berbagai macam hal terkait perawatan kesehatannya yang perlu diperhatikan baik oleh pasien maupun keluarga pasien dalam merawat pasien diabetes melitus, diantaranya pemantauan terhadap kadar gula darah, pengendalian dan pemantauan diabetes melitus secara berkelanjutan, penyulit dan komplikasi dalam diabetes melitus, intervensi non-farmakologis, serta penggunaan obat-obatan.

Discharge planning model LIMA dikembangkan berdasarkan hasil temuan survei, kajian teori dan hasil penelitian. Hasil uji statistik menunjukkan bahwa pengembangan perencanaan pulang model LIMA mempunyai pengaruh yang signifikan terhadap pelaksanaan perencanaan pulang yang dilakukan oleh perawat (Fitri, Herliawati, \& Wahyuni, 2018). Discharge planning model LIMA terdiri dari beberapa proses, yaitu (1) libatkan pasien dan keluarga dalam proses perencanaan pulang; (2) identifikasi kebutuhan perencanaan pulang pasien dan keluarga; (3) penggunaan metode 3 langkah dalam perencanaan pulang (saat pasien pertama dirawat di rumah sakit, satu hari sebelum pasien pulang, dan saat hari kepulangan pasien); (4) analisis dan evaluasi kesiapan pasien dan keluarga (Fitri, 2018).

Studi literatur menunjukkan banyak model discharge planning yang dilakukan secara komprehensif yang dapat digunakan bagi pasien dan keluarga. Di Indonesia, khususnya di Kota Palembang model pelaksanaan discharge planning dalam bentuk menyediakan lembar pemulangan yang berisi jadwal kontrol dan medikasi yang harus dikonsumsi oleh pasien. Selain itu, dalam pelaksanaannya model tradisional ini tidak banyak melibatkan multidisiplin dan perawat tidak banyak melakukan pengkajian, intervensi, dan edukasi serta evaluasi kesiapan pulang pasien dan keluarga. Kelemahan dari model ini adalah pasien dan keluarga tidak memahami intruksi perawatan mandiri di rumah dan kecenderungan pasien untuk kembali dirawat di rumah sakit lebih tinggi.

\section{METODE}

Jenis penelitian ini adalah rancangan quasi eksperimen dengan menggunakan rancangan one group pre-post design. Terdapat dua variabel dalam penelitian ini, yaitu variabel bebas (independent variable) yaitu pemberian discharge planning model LIMA, sedangkan variabel terikat (dependent variable) yaitu kesiapan pulang pasien diabetes melitus. Penelitian dilakukan di dua ruang rawat inap penyakit dalam di rumah sakit X Palembang pada bulan Agustus-Oktober 2019. Sampel dalam penelitian ini adalah pasien diabetes melitus yang dirawat di rumah sakit $X$, dengan kriteria inklusi: pasien diabetes melitus dengan kondisi hemodinamik stabil, dan pasien dan keluarga pasien bersedia menjadi responden.

Kesiapan pulang pada pasien diabetes melitus menggunakan kuesioner Readiness for Hospital Discharge Scale (RHDS) yang dikembangkan oleh Weiss \& Piancentine (2006). Kuesioner RHDS meliputi 21 item pertanyaan yang mengukur persepsi pasien terhadap kesiapan pulang dari rumah sakit yang terdiri dari empat faktor kesiapan pulang, yaitu: status personal, pengetahuan, kemampuan koping, dan dukungan. Skor yang lebih tinggi menunjukkan kesiapan yang lebih besar untuk dipulangkan.

Analisis bivariabel dilakukan dengan menggunakan uji $t$ berpasangan untuk mengetahui pengaruh discharge planning model LIMA terhadap kesiapan pulang pasien diabetes melitus. Besarnya peluang salah dalam menolak Ho dari data penelitian digambarkan dengan nilai $p$, 
untuk mengetahui ada tidaknya pengaruh antara variabel bebas dengan variabel terikat maka keputusan analisis statistik diambil dengan cara membandingkan nilai $p$ dengan nilai alfa $(\alpha=0,05)$ diterima jika nilai $\mathrm{p}>0,05$.

\section{HASIL}

Hasil penelitian menunjukkan bahwa nilai rata-rata pretest lebih rendah daripada nilai post test status personal, maka dapat disimpulkan terdapat perbedaan nilai ratarata status personal sebelum dan sesudah dilakukan intervensi. Hasil analisis menunjukkan bahwa ada pengaruh pemberian discharge planning model LIMA terhadap kesiapan pulang pasien dengan diabetes mellitus.

Rata-rata pengetahuan pre-test lebih rendah daripada post-test, sehingga disimpulkan terdapat perbedaan nilai ratarata pengetahuan sebelum dan sesudah dilakukan intervensi. Hasil penelitian menunjukkan bahwa ada perbedaan ratarata nilai pre-test dan post-test pengetahuan secara signifikan, yang artinya ada pengaruh pemberian discharge planning model LIMA terhadap kesiapan pulang pasien dengan diabetes melitus.

Rata-rata kemampuan koping pre-test lebih rendah daripada post-test sehingga disimpulkan terdapat perbedaan nilai ratarata kemampuan koping sebelum dan sesudah dilakukan intervensi. Hasil penelitian menunjukkan bahwa ada pengaruh pemberian discharge planning model LIMA terhadap kesiapan pulang pasien dengan diabetes melitus.

Rata-rata nilai dukungan pre-test lebih rendah daripada post-test maka dapat disimpulkan bahwa terdapat perbedaan nilai rata-rata dukungan sebelum dan sesudah dilakukan intervensi. Hasil analisis menunjukkan bahwa ada pengaruh pemberian discharge planning model LIMA terhadap kesiapan pulang pasien dengan diabetes melitus.
Rata-rata nilai kesiapan pulang pre-test lebih rendah daripada post-test maka dapat disimpulkan bahwa terdapat perbedaan nilai rata-rata kesiapan pulang sebelum dan sesudah dilakukan intervensi. Hasil analisis menunjukkan bahwa ada pengaruh pemberian discharge planning model LIMA terhadap kesiapan pulang pasien dengan diabetes melitus.

\section{Tabel 1}

Perbedaan kesiapan pulang sebelum dan setelah dilakukan discharge planning model LIMA

\begin{tabular}{lccc}
\hline \multicolumn{1}{c}{ Indikator } & Pre-test & Post-test & $\mathrm{p}$ \\
\hline Status & 20,71 & 36,84 & $0,0001^{*}$ \\
personal & $(3,968)$ & $(5,324)$ & \\
\hline Pengetahuan & 24,68 & 54,55 & $0,0001^{*}$ \\
& $(5,793)$ & $(7,899)$ & \\
\hline Kemampuan & 8,58 & 21,65 & $0,0001^{*}$ \\
koping & $(2,838)$ & $(2,893)$ & \\
\hline Dukungan & 8,00 & 21,29 & $0,0001^{*}$ \\
& $(2,781)$ & $(3,551)$ & \\
\hline Kesiapan & 65,10 & 141,42 & $0,0001^{*}$ \\
pulang & $(9,325)$ & $(17,534)$ & \\
\hline * paired t-test & & & \\
& & &
\end{tabular}

\section{PEMBAHASAN}

Diabetes mellitus termasuk ke dalam kategori penyakit kronis yang membutuhkan perawatan medis dengan tujuan untuk mencegah atau mengurangi risiko terjadinya komplikasi (Diabetes care, 2015). Diabetes melitus ditandai dengan terjadinya gangguan metabolisme yang ditandai dengan adanya hiperglikemi akibat abnormalitas metabolisme karbohidrat, lemak dan protein (Perkumpulan Endrokrinologi Indonesia, 2015).

Hasil penelitian menunjukkan bahwa terdapat perubahan nilai yang signifikan kesiapan pulang pasien dengan diabetes melitus sebelum dan setelah intervensi discharge planning model LIMA. Hasil penelitian ini sejalan dengan penelitian sebelumnya oleh Wahyuni, Nurrachmah, \& Gayatri (2012) yang menunjukkan adanya peningkatan kesiapan pulang pada responden setelah diberikan discharge planning terprogram selama 7 hari dan penelitian oleh Siahaan (2009) bahwa terjadi peningkatan pada tingkat kesiapan 
pulang pasien post operasi abdominal akut setelah intervensi discharge planning.

Melalui discharge planning yang terstruktur dapat meningkatkan transisi perawatan pasien yang lancar dari rumah sakit ke rumah. Discharge planning yang tidak memadai merupakan kontributor utama terhadap penurunan kualitas perawatan dan inefisiensi biaya perawatan kesehatan yang boros. Ketika pasien dipulangkan dari rumah sakit, pasien akan menerima informasi yang beragam tentang bagaimana melakukan perawatan di rumah secara mandiri, medikasi yang harus dikonsumsi, gejala-gejala komplikasi yang harus diwaspadai, dan siapa petugas kesehatan yang dapat dihubungi jika mengalami kendala dalam perawatan di rumah (Petitgout, 2015).

Kesiapan pulang pada penelitian ini dinilai dengan menggunakan kuesioner Readiness for Hospital Discharge Scale (RHDS) yang dikembangkan oleh Weiss \& Piancentine (2006). Kuesioner RHDS meliputi 21 item pertanyaan yang mengukur persepsi pasien terhadap kesiapan pulang dari rumah sakit yang terdiri dari empat faktor kesiapan pulang, yaitu: status personal, pengetahuan, kemampuan koping, dan dukungan. Status personal diartikan sebagai pernyataan fisikemosional pasien segera sebelum pulang. Pengetahuan diartikan sebagai persepsi kecukupan informasi yang dibutuhkan untuk menanggapi masalah dan masalah yang sama pada periode pasca rawat inap. Kemampuan koping mengacu pada kemampuan yang dirasakan pasien untuk mengatur sendiri kebutuhan perawatan pribadi dan kesehatan setelah dipulangkan. Dukungan yang diharapkan didefinisikan sebagai bantuan emosional dan instrumental yang diharapkan tersedia setelah pasien keluar dari rumah sakit dan didukung dengan baik transisi ke perawatan berbasis rumah (Weiss \& Piancentine, 2006).

Hasil penelitian menunjukkan bahwa setelah pemberian intervensi discharge planning model LIMA, terjadi peningkatan skor rata-rata pada keempat faktor kesiapan pulang (status personal, pengetahuan, kemampuan koping, dan dukungan) dengan nilai sig (2 tailed) masing-masing faktor adalah sebesar 0,000. Status personal menggambarkan tentang seberapa siap fisik dan emosional pasien dalam menghadapi pemulangan. Pada pasien dengan diabetes melitus self management merupakan hal yang sangat penting. Melalui discharge planning model LIMA pasien disiapkan secara fisik dan emosional dalam menghadapi pemulangan dengan cara perawat melakukan pengkajian terhadap kebutuhan kesiapan pulang pasien dan keluarga selama pasien dirawat di rumah sakit. Dari hasil penelitian juga menunjukkan adanya peningkatan skor rata-rata pada faktor pengetahuan setelah diberikan intervensi discharge planning model LIMA. Hal ini disebabkan karena perawat melakukan pengkajian terhadap kebutuhan pendidikan kesehatan bagi pasien dan keluarga dan perawat memberikan informasi dan edukasi kesehatan tentang perawatan pasien diabetes melitus setelah pulang dari rumah sakit.

American Diabetes Association (2019) mengemukakan bahwa diabetes melitus adalah penyakit kronis yang membutuhkan perawatan yang kompleks untuk mencegah terjadinya komplikasi akut dan juga mengurangi risiko komplikasi lanjutan. Penelitian oleh Rondhianto (2012) menunjukkan bahwa edukasi self management diabetes dapat mendukung pengetahuan, keterampilan dan kemampuan perawatan diri pasien dalam kesiapan pulang sehingga pasien mampu berprilaku mandiri melakukan perawatan terhadap dirinya (nilai $\mathrm{p}=0.000$ ). Sejalan dengan penelitian tersebut, intervensi discharge planning model LIMA meliputi keterlibatan pasien dan keluarga dalam proses discharge planning; identifikasi kebutuhan discharge planning bagi pasien dan keluarga (perawatan diri di rumah, penjelasan tentang obat-obatan, 
pengenalan tanda dan gejala yang harus diwaspadai oleh pasien dan keluarga, penjelasan hasil tes laboratorium atau pemeriksaan diagnostik, jadwal kontrol); penggunaan metode tiga langkah dalam pelaksanaan discharge planning (saat pasien baru dirawat di rumah sakit, satu hari sebelum pasien diizinkan untuk pulang, dan pada hari kepulangan pasien); dan evaluasi terhadap kesiapan pulang pasien dan keluarga (Fitri, Herliawati, \& Wahyuni, 2018).

Penderita diabetes melitus harus menerima perawatan medis dari tim yang dikoordinasi dokter dan termasuk di dalamnya adalah dokter, perawat, ahli diet, apoteker, dan profesional kesehatan mental dengan keahlian dalam diabetes melitus. Pendekatan tim kolaboratif dan terintegrasi memgang peran yang sangat penting dalam perawatan pasien dengan diabetes melitus (ADA, 2019). Discharge planning model LIMA merupakan suatu proses pemulangan yang dilakukan secara terintegrasi antar interdisiplin dan dikoordinasikan oleh perawat dalam rangka memfasilitasi pemulangan bagi pasien dan keluarga yang dilakukan sejak awal pasien dirawat sampai dengan hari kepulangan pasien. Model ini menggambarkan bahwa pasien dan keluarga dipersiapkan pemulangannya dengan tujuan agar kontinuitas perawatan mandiri di rumah tidak terputus dan upaya layanan rumah sakit terkoordinasi dengan layanan kesehatan yang ada di sekitar komunitas/ tempat tinggal pasien. Pasien dan keluarga diberikan informasi yang mendetil mengenai penyakitnya, batasan, tanda dan gejala yang harus diwaspadai, diet, terapi, medikasi, dan edukasi pengetahuan dan keterampilan dalam melakukan perawatan mandiri di rumah.

Discharge planning seperti yang dideskripsikan dalam literatur merupakan sebuah proses. Dalam tatanan rumah sakit, discharge planning didefinisikan sebagai proses melalui perawat sebagai koordinator perawatan kesehatan bertanggung jawab terhadap pasien. Efektif discharge planning adalah yang efisien, menggunakan standar praktik yang terbaik, melibatkan pasien dan keluarga mulai dari hari pertama dirawat sampai pasien siap dipulangkan ke rumah, serta bersifat inklusif dan menyediakan upaya layanan terkoordinasi dari rumah sakit kepada komunitas di sekitar tempat tinggal pasien (Petitgout, 2015).

Discharge planning diinisiasi pada semua pasien dengan diabetes melitus. Perawatan bagi pasien dengan penyakit diabetes melitus merupakan $90 \%$ perawatan mandiri, sehingga edukasi menjadi peran penting dalam perawatan pasien. Pasien yang baru saja didiagnosa atau diidentifikasi mempunyai keterbatasan pengetahuan tentang diabetes melitus harus mendapatkan edukasi yang memadai seperti manajemen medikasi, nutrisi, latihan/ aktivitas fisik, hiperglikemia, hipoglikemia, pentingnya monitoring kadar gula darah dan panduan perawatan, di samping informasi kontak untuk dalam keadaan darurat dan rencana post discharge untuk dukungan pendidikan berkelanjutan di rumah (Arnold, et al., 2016). Pelayanan kesehatan di rumah sakit yang berfokus pada manajemen diabetes pada pasien yang dirawat, edukasi, dan discharge planning akan meningkatkan kontrol glikemik pada pasien diabetes tipe 2 dan hemoglobin A1c (HbA1c) > 7.5\% (58 mmol $/ \mathrm{mol}$ ) dalam satu tahun pasien dipulangkan ke rumah (Wexler, et al., 2012).

Pemberian informasi yang memadai bagi pasien dan keluarga selama masa perawatan di rumah sakit dapat memberikan dampak yang positif, sehingga pasien dan keluarga dapat membantu diri sendiri selama proses penyembuhan di rumah. Informasi yang kurang dan tidak jelas akan membawa dampak negatif seperti kesalahan saat mengonsumsi obatobatan, pola makan yang buruk, atau mengabaikan kegiatan setelah pulang dari rumah sakit. Pendidikan kesehatan yang tepat selama pasien dirawat di rumah sakit sangat penting dalam meningkatkan 
kemampuan untuk mengelola penyakit, karena dengan manajemen yang baik, komplikasi diabetes akut dan kronis dapat dihindari.

\section{Discharge planning model LIMA} memfasilitasi proses edukasi yang secara rutin selama pasien dirawat di rumah guna mempersiapkan pasien dan keluarga memiliki pengetahuan dan keterampilan yang cukup memadai untuk dapat melakukan perawatan di rumah dengan baik. Selain itu, model LIMA juga memberikan uraian tugas yang jelas masing-masing interdisiplin yang secara terintegrasi memberikan edukasi dan informasi yang dibutuhkan oleh pasien dan keluarga dalam menghadapi pemulangan. Manajemen diri yang tepat saat pasien dirawat di rumah sakit harus menjadi tolok ukur yang disepakati oleh dokter atau penyedia perawatan primer, perawat dan pasien (ADA, 2019). Sangat penting bahwa keterampilan manajemen diri yang benar disampaikan agar pasien dengan diabetes melitus dapat beralih ke rumah dengan keterampilan yang memadai yang diperlukan untuk merawat dirinya.

Implementasi yang baik dari discharge planning memungkinkan pasien untuk mandiri dalam perawatan diri sendiri dan memastikan bahwa pasien dapat mengambil perawatan tindak lanjut yang aman dan realistis setelah meninggalkan rumah sakit (Potter \& Perry, 2006).

\section{SIMPULAN}

Discharge planning model LIMA mempunyai pengaruh yang signifikan terhadap kesiapan pulang pada pasien diabetes melitus yang dirawat rumah sakit. Discharge planning yang sistematis, terstruktur, dan aplikatif dapat memberikan manfaat dalam mempertahankan kontinuitas perawatan lanjutan bagi pasien terutama dengan kondisi kronis maupun yang membutuhkan perawatan paliatif.

\section{UCAPAN TERIMAKASIH}

Penulis mengucapkan terimakasih kepada semua pihak yang telah mendukung dalam penelitian ini.

\section{REFERENSI}

American Diabetes Association. (2019). Introduction: Standards of Medical Care in Diabetes-2019. Diabetes Care, Volume 42, Supplement 1, January 2019. https://doi.org/10.2337/dc19-Sint01

Arnold, P., et al. (2016). Hospital Guidelines for Diabetes Management and the Joint Commission-American Diabetes Association Inpatient Diabetes Certification. American Journal of the Medical Scienes Vol 351 (4): 333-341.

DOI: 10.1016/j.amjms.2015.11.024

Diabetes Care. (2015). Standards Of Medical Care In Diabetes. American Diabetes Association. The Journal of Clinical And Applied Research And Education www.diabetes.org/

Dougherty, Lister \& West-Oram. (2015). The Royal Marsden Manual of Clinical Nursing Procedures. Ninth Edition, Student edition

Fitri, E.Y. (2018). Modul Perencanaan Pulang LIMA. Tidak dipublikasikan.

Fitri, E.Y., Herliawati, \& Wahyuni, D. (2018). Karakteristik, Pengetahuan, dan Pelaksanaan Perencanaan Pulang yang Dilakukan oleh Perawat. Prociding Seminar Nasional Keperawatan Universitas Sriwijaya 2018.

Graham, J., Gallagher, R. \& Bothe, J. (2013). Nurses' Discharge Planning and Risk Assessment: Behaviours, Understanding and Barriers. Journal of Clinical Nursing, 22, 2338-2346.

https://doi.org/10.1111/jocn.12179

Nursalam. (2014). Manajemen Keperawatan: Aplikasi dalam Praktik Keperawatan Profesional. Edisi 4. Jakarta: Salemba Medika

Perkumpulan Endokrinologi Indonesia. (2015). Konsesus pengelolaan dan pencegahan diabetes mellitus tipe 2 di Indonesia tahun 2011. PERKENI. 
Petitgout, J.M. (2015). Implementation and Evaluation of a Unit-Based Discharge Coordinator to Improve the Patient Discharge Experience. Journal of Pediatric Health Care Vol 29 No.6, November 2015 hal. 509-517. http://dx.doi.org/10.106/j.pedhc.2015.02. 004 .

Potter, A \& Perry, A.G. (2006). Buku Ajar Fundamental Keperawatan. Edisi 4. Jakarta : EGC.

Rondhianto, R. (2012). Pengaruh diabetes self management education dalam discharge planning terhadap self care behavior pasien Diabetes Mellitus Tipe 2. Jurnal Keperawatan Soedirman, 7(3), 133-141.

Siahaan, M. (2009). Pengaruh Discharge Planning yang Dilakukan oleh Perawat terhadap Kesiapan Pasien Pasca Bedah Akut Abdomen Menghadapi Pemulangan Di RSUP H. Adam Malik Medan. USU Repository.

Wahyuni, A., Nurrachmah, E., \& Gayatri, D. (2012). Kesiapan pulang pasien penyakit jantung koroner melalui penerapan discharge planning. Jurnal keperawatan indonesia, 15(3), 151-158.

Weiss, M \& Piancentine, L. (2006). Psychometric Properties of the Readiness for Hospital Discharge Scale. Journal of Nursing Measurement, Vol. 14 No. 3 (Desember 2006): 163-180. DOI: $10.1891 / \mathrm{jnm}-$ v14i3a002.

Wexler, D.J., et al. (2012). Impact of Inpatient Diabetes Management, Education, and Improved Discharge Transition on Glycemic Control 12 Months After Discharge. Diabetes Research and Clinical Practice 98 (2012): 249-256. http://dx.doi.org/10.1016/j.diabres.2012.0 9.016 